\title{
Sprawozdanie z konferencji XIX Balcanicum: Granice na Batkanach $i$ w Europie Środkowej a praktyka życia codziennego (Poznań, 23-24 X 2020 r.)
}

Dziewiętnasta konferencja z cyklu Balcanicum, Granice na Bałkanach i w Europie Środkowej a praktyka życia codziennego odbyła się w Poznaniu (w formie zdalnej) 23 i 24 X 2020 r. Została zorganizowana przez Wydział Historii Uniwersytetu im. Adama Mickiewicza i Komisję Bałkanistyki przy Oddziale PAN w Poznaniu, której posiedzenie poprzedziło właściwą część obrad. Tematyka konferencji dotyczyła różnych aspektów zjawiska pograniczności w ogólnie rozumianej przestrzeni bałkańskiej i środkowoeuropejskiej, w przeszłości oraz współcześnie. Konferencja zgromadziła 16 uczonych zajmujących się problematyką bałkańską i środkowoeuropejską: historyków, politologów i etnologów. Wystąpienia charakteryzowała rozległa tematyka dotycząca pograniczy, chronologicznie obejmująca okres od wczesnego średniowiecza po współczesność.

Referaty poruszały m.in. kwestie zmiany granic politycznych. Zdzisław Pentek (UAM) przedstawił problem zmienności granic Tracji w okresie Cesarstwa Łacińskiego, a Katarzyna Niemczyk (Katowice, Uniwersytet Śląski) omówiła problem przynależności Siedmiogrodu po 1526 r. Jeśli chodzi o referaty dotyczące wieku XX, to należy wspomnieć o tekstach Krzysztofa Nowaka (Uniwersytet Śląski), który przeanalizował proces kształtowania się granic Czechosłowacji i Rumunii po pierwszej wojnie światowej, czy Jędrzeja Paszkiewicza (Poznań, UAM), który przybliżył zagadnienie aktywności ustaszy na pograniczu węgiersko-jugosłowiańskim w pierwszej połowie lat trzydziestych XX w. Część wystąpień dotyczyła granic Jugosławii $\mathrm{w}$ czasach powojennych, a także w momencie jej rozpadu. Zaliczyć do nich można wystąpienia Pawła Wawryszuka (Bydgoszcz, UKW), który przedstawił temat służby duchownych w Jugosłowiańskiej Armii Ludowej, Mateusza Sokulskiego (Katowi- 
ce, Uniwersytet Śląski) który przybliżył postawę jugosłowiańskich elit wobec granic w Jugosławii w latach osiemdziesiątych XX w., czy Dariusza Wybranowskiego (Uniwersytet Szczeciński), który omówił polityczne i etniczne uwarunkowania powstania Dystryktu Brcko jako elementu zmiany granic wewnętrznych w Bośni i Hercegowinie po $1995 \mathrm{r}$.

Wiele z przedstawionych prezentacji skupiało się na wpływie, jaki podziały polityczne wywierały na społeczności obszarów pograniczy, np. Pomaków z Babiaku (Krzysztof Popek, Kraków, Uniwersytet Jagielloński) czy Wołochów żyjących na styku terytoriów albańskich i macedońskich (wystąpienie Ewy Kocój, również z Uniwersytetu Jagiellońskiego). Podobną perspektywę prezentowały referaty Ilony Czamańskiej (UAM), omawiający sytuację chłopów serbskich w okresie trwania Komendantury Wojskowej Królestwa Serbii, czy Wojciecha Sajkowskiego (UAM), dotyczący pogranicznego charakteru społeczności dalmatyńskiego interioru w źródłach francuskojęzycznych z początku XIX w.

Kwestia graniczności nie dotyczy jedynie zagadnień politycznych, stąd podczas konferencji przedstawiono referaty dotyczące granic kulturowych, religijnych i społecznych. Jarosław Dudek (Uniwersytet Zielonogórski) przedstawił ciekawe ujęcie tematu pograniczności, koncentrując się na relacjach kultur i warstw społecznych w czasie odrodzenia się średniowiecznej państwowości bułgarskiej pod panowaniem rodu Asenidów. Z kolei Wawrzyn Kowalski (Uniwersytet Wrocławski) omówił problem granic ekumeny w Historii Salony Tomasza Archidiakona i w Latopisie popa Duklanina, a Tomasz Lis (Toruń, Wyższa Szkoła Kultury Społecznej i Medialnej) - problem postrzegania austro-węgierskiego dziedzictwa na Bałkanach.

Część prelegentów analizowała kwestię pograniczy w aspekcie lokalnym, np. w obrębie jednego miasta. Magdalena Rekść (Uniwersytet Łódzki) przedstawiła zagadnienie mitu olimpiady w Sarajewie w kontekście przemian granic po rozpadzie Jugosławii. Z kolei Anna Jagiełło-Szostak (Uniwersytet Wrocławski) przybliżyła Kosowską Mitrowicę jako przykład podzielonego miasta i obszar „zamrożonego” konfliktu etnicznego.

Referatom towarzyszyły ożywione dyskusje. Podsumowując całość obrad, można pokusić się o ogólny wniosek, że Bałkany i Europa Środkowa są charakteryzowane w badaniach i literaturze naukowej przy wykorzystaniu rozmaitych granic wyznaczających obszary oddziaływań cywilizacyjnych, wpływów religijnych, kulturowych, politycznych czy ekonomicznych. Granice te, funkcjonujące w różnych okresach, krótkotrwałe lub długowieczne, nierzadko narzucane siłą z zewnątrz, przyczyniły się do ukształtowania zróżnicowanej specyfiki regionów, a nawet konkretnych miejsc. 
Nadesłany: 5 I 2021

Zaakceptowany: 7 I 2021

Dr hab. Wojciech Sajkowski, prof. UAM

Wydział Historii

Uniwersytet im. Adama Mickiewicza w Poznaniu

ul. Uniwersytetu Poznańskiego 7

61-614 Poznań 